\section{El General Medical Council revisa un documento clave: Tomorrow's Doctors}

Arcadi Gual

\section{The General Medical Council revises a key document: Tomorrow's Doctors}

En la página web [1] del General Medical Council (GMC) británico encontramos desde el día 2 de septiembre una nueva versión, muy actualizada respecto a la primera publicada en 1993, de uno de los documentos más relevantes para la formación de los médicos: Tomorrow's Doctors. Tan relevante nos parece que le dedicamos este editorial con la intención de que quienes no conozcan el documento tengan la oportunidad de leerlo, y quienes ya conocían las dos versiones anteriores puedan observar los cambios introducidos.

El documento va dirigido a la formación de grado, esto es, a la formación de los estudiantes de las facultades de medicina, pero no se detiene en los estudios universitarios, sino que contempla las tres etapas del continuo educativo y esa es la primera virtud del trabajo. La formación de grado, la especializada y la formación continuada no deben contemplarse, ni menos aún administrarse (gestionarse), como compartimentos estancos.

En su introducción, una página corta pero de gran contenido, se exponen las obligaciones -repito, obligaciones- de todo médico que quiera estar registrado en el GMC. Éstas se resumen en seis epígrafes que podrán encontrar y leer en el documento, pero me permitirán transcribir una frase tomada del Good Medical Practice, también del GMC, en la que se inspiran los seis apartados: 'Los buenos médicos hacen que la asistencia de sus pacientes sea su primera preocupación; son competentes, mantienen sus conocimientos y habilidades actualizados, establecen y mantienen buenas relaciones con
Since 2nd September the British General Medical Council (GMC) website [1] now offers a new updated version of one of the most significant documents in the training of physicians, Tomorrow's Doctors, which was first published in 1993. We deem this work to be of such importance that we have devoted this editorial to it so that those who are not familiar with the document will have the chance to read it and those who are already acquainted with the two previous versions can see the changes that have been introduced.

The document deals with undergraduate training, that is to say, the training of students in faculties of medicine, but it is not limited to university education and also covers the three stages of the educational continuum, which is the prime virtue of this invaluable work. Graduate, specialised and continuous training must not be considered or, even more important, administered (or managed) as though they were watertight compartments.

Its introduction, one short but fertile page, outlines the obligations -that's right, I said obligations - to be fulfilled by any physician who wishes to be registered in the GMC. These $d u$ ties are summarised in six sections that can be found and read in the document, but I would like to take the liberty of transcribing a sentence from Good Medical Practice, also written by the GMC, which serves as inspiration for the six sections: 'Good doctors make the care of their patients their first concern: they are competent, keep their knowledge and skills up to date, establish and maintain good relationships with
Director de Educación Médica. Secretario de la SEDEM.

E-mail agual@ub.edu 
sus pacientes y con sus colegas, son honrados y dignos de confianza, y actúan con integridad'.

En la primera parte del documento se repasan las diferentes responsabilidades de los cinco actores principales del Reino Unido en la formación de los médicos: el GMC, las facultades de medicina, el Servicio Nacional de Salud (NHS), los médicos $\mathrm{y}$, naturalmente, los estudiantes; estas responsabilidades, como no podía ser menos, se complementan entre sí para completar el cuadro de la formación de los médicos. Es de interés comentar alguna de estas responsabilidades ya que, al explicitarlas, se incrementa el valor que de por sí ya tienen.

Entre las responsabilidades del GMC figura la de promover un estándar de alto nivel de calidad en la educación médica, pero nos parece más interesante comentar la responsabilidad, 'decisoria', del GMC sobre los conocimientos, habilidades $\mathrm{y}$ actitudes que requieren los candidatos, y también la de asegurar que los recursos previstos para la enseñanza y el aprendizaje permiten a los estudiantes adquirir los requisitos del GMC.

Parece obvio que, entre otras responsabilidades, las facultades de medicina deben gestionar y mejorar la calidad de sus programas, proveer a los estudiantes y a los profesores el soporte académico necesario, y preservar el principio de igualdad. Pero sin menospreciar los puntos anteriores destaca, a nuestro entender, la responsabilidad de las facultades de medicina en la selección de sus estudiantes y la responsabilidad de asegurar que solamente se gradúan los alumnos que han mostrado poseer las competencias definidas por el GMC.

Por su parte, el NHS se responsabiliza, lógicamente, de facilitar el soporte, las infraestructuras y los recursos humanos necesarios para la enseñanza clínica, pero también es responsable de la formación de los médicos como docentes y de asegurar que la actuación docente se evalúe convenientemente.

Los médicos son responsables de mantener los principios de la práctica profesional según el Good Medical Practice, de desarrollar las habilidades y prácticas de un profesor competente, supervisar a sus estudiantes para favorecer su aprendizaje y garantizar la seguridad de los pacientes.

Finalmente, los estudiantes no están exentos de responsabilidades. En primer lugar, son responsables de su propio aprendizaje, incluyendo todos los objetivos del Tomorrow's Doctor, cualesquiera que sean sus preferencias o creencias patients and colleagues, are honest and trustworthy, and act with integrity'.

The first part of the document reviews the different duties to be fulfilled by the five leading players in doctor training in the United Kingdom, i.e. the GMC, faculties of medicine, the National Health Service (NHS), physicians and, of course, students. These duties, as is to be expected, supplement one another and together go to complete the training of physicians. It is interesting to discuss some of these duties because simply detailing them increases the intrinsic value that they already have.

One of the duties of the GMC is to promote a high standard of quality in medical education. Yet, it seems still more interesting to comment on the 'decision-making' duties of the GMC as regards the knowledge, skills and attitudes required of candidates, as well as on the responsibility it has to ensure that the resources allocated for teaching and learning are sufficient to allow students to reach the GMC's requirements.

It seems obvious that, among other duties, faculties of medicine must manage and improve the quality of their programmes of study, provide students and faculty with the academic support they need, and uphold the principle of equality. But although we acknowledge the value of the previous points, as we understand it the main responsibility of faculties of medicine lies in the process of selecting their students and their duty to ensure that only students who have proved to be in possession of the outcomes required by the GMC graduate at the end of their studies.

The NHS, obviously, is responsible for providing the media, facilities and human resources needed for clinical teaching, but it is also responsible for training doctors as teachers and for ensuring that teaching is assessed in an appropriate way.

Physicians are responsible for maintaining principles of professional practice in accordance with Good Medical Practice, for developing the skills and practical abilities of competent teachers, and for supervising their students in order to further their learning and to guarantee patients' safety.

Finally, students also have to carry out a number of duties. First of all, they are responsible for their own learning, including all the aims of Tomorrow's Doctors, whatever their preferences or religious beliefs might be. They must 
religiosas. Deben responsabilizarse de la seguridad de los pacientes manteniéndose siempre en los límites de su competencia, y deben hacer explícita cualquier preocupación sobre la seguridad del paciente o sobre la conducta de otros incompatible con la buena práctica profesional.

No es difícil percibir que nuestro sistema muestra ciertos paralelismos, pero destaca más por las diferencias. Es muy probable que en el terreno teórico muchas sino todas las responsabilidades expuestas serían fácilmente consensuadas en nuestro entorno sociocultural. Sin embargo, la estructura de nuestro sistema educativo, rígida y en compartimentos estancos, no sólo lo dificultan, sino que de hecho lo impide. ¿Es posible que algo en lo que todos estamos de acuerdo no se pueda hacer?

En la segunda parte del documento se revisan los 'Outcomes for graduates', que debemos entender como los resultados del aprendizaje y que según su profundidad o generalidad pueden definirse como competencias. Se agrupan en tres secciones: el médico como académico y científico (5 ítems), el médico como asistencial (7 ítems) y el médico como profesional (4 ítems). En total, son 16 -jsólo 16!- las competencias que ha de adquirir un médico durante los estudios de grado (la licenciatura).

En la última parte del documento, la más extensa, se resumen los estándares, estructurados en 9 dominios o secciones (domains), que sería necesario alcanzar para poder enseñar, aprender y evaluar (se supone que satisfactoriamente). En esquema, son los siguientes: 1 . Seguridad del paciente; 2. Calidad (asegurarla, revisarla y evaluarla); 3. Igualdad, diversidad y oportunidad; 4. Admisión (selección) de estudiantes; 5. Diseño e impartición del currículo (incluida la evaluación); 6. Soporte y desarrollo de estudiantes, profesorado y personal estable de la institución; 7. Gestión de los procesos de enseñanza, aprendizaje y evaluación; 8. Infraestructura y recursos educativos; y 9. Definición de competencias.

Es difícil encontrar un documento relacionado con la formación de los médicos tan completo, que desde el marco conceptual llegue hasta los apartados más prácticos y concretos, que contemple la formación que ha de recibir un médico dentro del continuo educativo, que esté tan actualizado y se oriente a un contexto muy parecido al nuestro. Me pregunto si no es un buen referente para todas y cada una de nuestras universidades, nuestras instituciones sanitarias, take responsibility for patients' safety by always remaining within the limits of their skills and abilities, and they must voice any concerns about the patient's safety or about the conduct of others that may be incompatible with good professional practice.

It is not difficult to see that there are certain parallelisms with our own system, but there seem to be more differences than similarities. It is very likely that, as a theoretical proposal, an agreement could easily be reached in our sociocultural medium about many if not all of the duties mentioned. Nevertheless, the structure of our educational system in rigid, watertight compartments not only makes this difficult, but in fact prevents it altogether. How can it be impossible to implement something we all agree on?

The second part of the document reviews the 'Outcomes for graduates', which we must understand is being the results of the learning process they have followed. These outcomes are grouped in three sections: the doctor as a scholar and a scientist (five items), the doctor as a practitioner (seven items) and the doctor as a professional (four items). Altogether throughout their undergraduate studies, doctors have to acquire a total of 16 -only 16!- different outcomes.

The last, and longest, part of the document sets out the standards that would be expected for the delivery of teaching, learning and assessment (in a satisfactory way, we assume). Briefly, these standards are structured under the following nine domains: 1. Patient safety; 2. Quality (assurance, review and evaluation); 3. Equality, diversity and opportunity; 4. Student admission (selection); 5. Design and delivery of the curriculum (including assessment); 6. Support and development of students, teachers and the local faculty; 7. Management of teaching, learning and assessment; 8. Educational resources and capacity; and 9. Definition of outcomes.

It is difficult to find such a comprehensive up-to-date document on the training of doctors, one that covers everything from the conceptual framework to the most practical material matters. Very few works take into account the training a doctor has to receive within the educational continuum and are oriented towards a context that is so similar to our own. I believe it to be a good reference that could be of great value for each and every one of our universities, our health institutions, our health care services and our ad- 
nuestros sistemas de salud y nuestras administraciones. No me atrevo a pedir que los diferentes implicados copien esto o aquello del Tomorrows' Doctors, pero sí les pediré que lo lean, que lo lean un par de veces; no hacerlo sería imperdonable.

\section{Bibliografía}

1. General Medical Council. Tomorrows' Doctors. URL: http://www.gmc-uk.org/education/documents/gmc td_2009.pdf ministrations. I do not feel myself to be in a position to ask those involved to copy this or that from Tomorrow's Doctors, but I will ask them to read it, and to re-read it several times. To fail to do so would be unforgivable.

\section{References}

1. General Medical Council. Tomorrows' Doctors. URL: http://www.gmc-uk.org/education/documents/gmc td_2009.pdf 